\title{
16. PALYNOLOGY OF SITES 280-284, DSDP LEG 29, OFF SOUTHEASTERN AUSTRALIA AND WESTERN NEW ZEALAND
}

\author{
T. R. Haskell,' Robertson Research (North America) Ltd., Calgary, Canada, \\ and \\ G. J. Wilson, New Zealand Geological Survey, Lower Hutt, New Zealand
}

\begin{abstract}
The palynology of DSDP Sites 280 to 284 from the region adjacent to and south of Tasmania, and to the west of New Zealand is described, and the sequence is discussed in terms of the international stages. The early Cenozoic dinoflagellate assemblages at the sites have characteristic associations like those previously described from Antarctica and southern South America, but not like those from southern Australia or New Zealand. This forms a characteristic highlatitude early Cenozoic biogeographic province, about the time of separation of Australia from Antarctica. The presence in the sequences of reworked non-marine palynofloras of Permian, Triassic, and Cretaceous ages indicate that southeastern Australia contributed extensively to the Cenozoic sediments adjacent to and south of Tasmania.
\end{abstract}

\section{INTRODUCTION}

This paper deals with the palynology of representative material from the sequences cored at Sites 280 to 284 from Leg 29 of the Deep Sea Drilling Project (Figure 1). The material studied was taken from core catcher and section samples of the following cores:

Site 280, (Hole 280, Core 1); (Hole 280A, Cores 1-22)

Site 281, (Hole 281, Cores 2, 3, 6, 7, 9-17); (Hole 281A, Core 1)

Site 282, Cores 1, 4-18

Site 283, (Hole 283, Cores 2-17); (Hole 283A, Core 1)

Site 284, (Hole 284, Cores 1, 3, 5, 7, 9-22); (Hole 284A, Cores 2, 3)

The samples yielded variable palynofloras ranging from totally barren to well preserved and diverse, although most samples contain good fossil populations. Marine dinoflagellate cysts usually dominate the assemblages, both in diversity and numbers of specimens. However, angiosperm and gymnosperm pollen grains, as well as pteridophyte spores, are often well represented, and occasionally are dominant. Remanié (recycled) palynomorphs from late Paleozoic and/or Mesozoic strata are a consistent element of assemblages from some sections.

This initial examination and discussion was undertaken primarily to provide a palynostratigraphic breakdown of the sequences drilled at the various sites, using dinoflagellate and miospore data. Additional data

'Presently with Shell, B. P. and Todd Oil Services, New Plymouth, New Zealand.

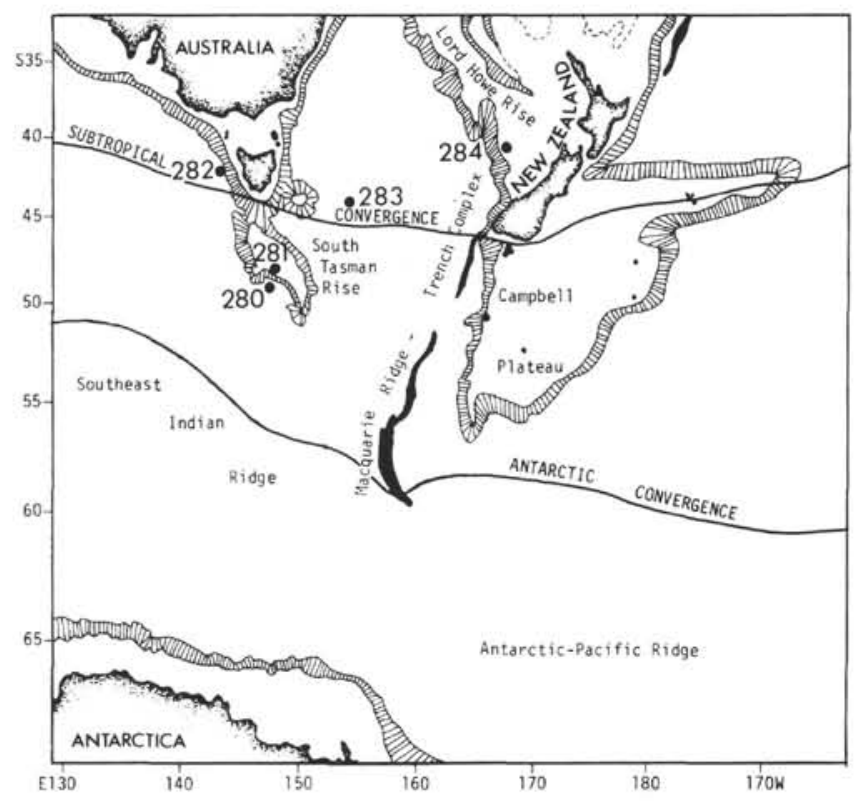

Figure 1. Location of Sites 280-284, DSDP Leg 29.

are included on gross population, variation of the remanié elements of the palynofloras, and comparisons of these palynofloras with those of Australia, New Zealand, South America, and Antarctica. Discussion of new forms and other systematic detail is not undertaken here. The assemblages are described from individual cores or groups of cores depending on the amount and type of variation. Where cores were examined by both authors the discussion represents a synthesis of results. 


\section{METHODS AND SAMPLE PREPARATION}

Palynological preparation of this material was undertaken in the laboratories of the Eastern Petroleum Section of the Geological Survey of Canada, Dartmouth, Nova Scotia, Canada; and at the New Zealand Geological Survey, Lower Hutt, New Zealand. Due to the soft, calcareous nature of the samples little treatment beyond solution of carbonate in dilute $\mathrm{HCl}$ was required. However, residues were occasionally treated with hydrofluoric acid or heavy liquid to further separate organic material from remaining, usually siliceous, mineral matter. Oxidation, acetolysis, and staining were used sparingly where necessary. Strew mounts were used exclusively. The mounts, and excess residues are being curated by the two organizations listed. Preparations (on Plates 1-4) prefixed by "L" are lodged in the Palynology Section, New Zealand Geological Survey; those prefixed "P" are held by the Eastern Petroleum Section of the Geological Survey of Canada.

Preparations of sectional samples of the cores listed were examined by T. R. H. Samples from Cores 10-22 of Hole 280A, Cores 13-17 of Site 281, Cores 4-18 of Site 282, and all cores from Site 283 were examined by G. J. W.

\section{SITE 280}

Palynofloras of Core 280-1 are extremely sparse, and samples of Cores 280A-1 to 280A-9 are either devoid of palynomorphs or yielded extremely sparse palynofloras. The only species with stratigraphic significance are single occurrences of Deflandrea phosphoritica Eisenack, 1938 in Section 280A-4-4 and Lejeunia hyalina Gerlach, 1961 in Section 280A-8-2. The former species has been widely reported from Oligocene and Eocene strata, and the latter is known from middle Eocene and Oligocene strata of Europe (Gerlach, 1961; Bujak, in press). The sequence in Cores $280 \mathrm{~A}-4$ to -8 is probably Oligocene, in view of the Eocene age established for the underlying cores. Occasional specimens of spore or pollen species are present in these assemblages of which Nothofagidites, usually $N$. matauraensis Couper, 1953, is most commonly encountered. However, though rare, remanié spores and saccate pollen grains predominate over contemporaneous specimens throughout this interval. Of the remanié forms, Alisporites grandis (Cookson) Dettmann, 1963, and A. similis (Balme) Dettmann, 1963 are more frequently encountered. These species are usually common elements of Australian Lower Cretaceous and Upper Jurassic palynofloras (Dettmann, 1963; Haskell, 1968). Rarer forms include Stereisporites antiquasporites (Wilson and Webster) Dettmann, 1963; Vitreisporites pallidis (Reissinger) Nilsson, 1958, which has a Permian-Lower Cretaceous range in Australia (Balme, 1957; Haskell, 1968); and Classopollis classoides Pflug emend Pocock and Jansonius, 1961, an uppermost Triassic-Lower Cretaceous species (Playford and Dettmann, 1965). Striate saccate grains of a type ranging through the Permian and Triassic (Evans, 1966) are present in Section 280A-7-4.

Core 280A-10 contains somewhat more diverse assemblages. These populations include Deflandrea macmurdoensis Wilson, 1967; D. antarctica Wilson, 1967; Turbiosphaera filosa (Wilson) Archangelsky, 1969; Spinidinium aperturum Wilson, 1967; and $S$. rotundum Wilson, 1967. Dinoflagellate populations, including these species, have been reported from Eocene strata of Antarctica (Wilson, 1967a) and South America (Archangelsky, 1968; Archangelsky and Fasola, 1971). Other dinoflagellate forms present include Deflandrea phosphoritica; Cleistosphaeridium $\mathrm{sp}$; Areosphaeridium dictyoplokus (Klumpp) Eaton, 1971; and (?)Chlamydophorella sp.

These palynofloras also contain several species of podocarp pollen including Podocarpites exiguus Harris, 1965 , as well as Nothofagidites matauraensis and other members of the Nothofagidites brassi and fusca groups, Triorites harrisii Couper, 1953, and occasional trilete spores. Remanie species similar to those from Cores 280A-1 to -9 are present in this core, and include Zonalapollenites trilobatus Balme, 1957, of Upper Jurassic to Lower Cretaceous age (Balme, 1957; Dettmann, 1963).

Core $280 \mathrm{~A}-11$ yielded palynofloras generally similar to those of Core 280A-10. Additional forms present include Leiosphaeridia telmatica Sarjeant and Strachan, 1968; and the Lower Cretaceous remanie grains Cycadopites nitidus (Balme) de Jersey, 1963; Lycopodiumsporites nodosus Dettmann, 1963; and Ischiosporites punctatus Cookson and Dettmann, 1958.

The dinoflagellate assemblage from Core $280 \mathrm{~A}-12$ is dominated by two species of Spinidinium, and also contains: Deflandrea antarctica; $D$. distinctum Wilson, 1967; Leptodinium victorianum Cookson and Eisenack, 1965; and Spiniferites wetzeli (Deflandre) Sarjeant, 1970. Pollen grains, which are less common than the dinoflagellate cysts, include the species Nothofagidites flemingii Couper, 1953, and Triorites harrisii. Spore populations are sparse, but Plicifera delicata (Bolkhovitina) Bolkhovitina, 1966 is present. The dinoflagellate assemblage, as well as the presence of $N$. flemingii, a New Zealand Bortonian-Runangan (middleupper Eocene) form (Couper, 1960), indicates that this core is also middle to upper Eocene. Few remanié forms were noted, but include the Lower Cretaceous species Alisporites grandis and Lycopodiumsporites eminulus Dettmann, 1963.

Palynofloras from Core 280A-13 are relatively rich, and are dominated by the dinoflagellate Spinidinium rotundum Wilson, 1967, which locally comprises over $80 \%$ of the total palynofloral population. Associated species include Deflandrea asymmetrica Wilson, 1967; Deflandrea phosphoritica phosphoritica; D. phosphoritica australis Cookson and Eisenack, 1961; D. antarctica; D. macmurdoensis; Cyclonephelium $\mathrm{cf}$. australis (similar to a species described by Pöthe de Baldis [1966] from the lower Tertiary of southernmost South America); Spiniferites ramosus Ehrenberg, 1835; Leptodinium victorianum; L. dispertitum; Cleistosphaeridium sp.; Palaeoperidinium sp. 1; Palaeoperidinium sp. 2, and Areosphaeridium dictyoplokus. Pollen grains and spores are considerably less common with Nothofagidites matauraensis being the most abundant species, in association with $N$. flemingii, Triorites harrisii, Proteacidites annularis Cookson, 1950, Beaupreaeidites 
elegansiformis Cookson, 1956, and Cicatricosisporites australiensis (Cookson) Potonié, 1956. A middle to upper Eocene age is indicated for Core 280A-13.

The remanié palynofloras include Deflandrea $\mathrm{cf}$. $D$. diebeli Alberti, 1959, an Upper Cretaceous form; Alisporites grandis; A. similis; Lycopodiumsporites eminulus; L. circolumenus Dettmann, 1963, Lower Cretaceous; and the Lower Jurassic pollen grain Classopollis simplex (Danzé-Corsin and Lavine) Reiser and Williams, 1969.

Core 280A-14 is very similar to Core 13, with Spinidinium still the dominant genus, although in Section 2, Deflandrea antarctica and Areosphaenidium dictyoplokus are common. Other dinoflagellate species present include Thalassiphora pelagica (Eisenack) Eisenack and Gocht, 1960; Aiora fenestrata (Deflandre and Cookson) Cookson and Eisenack, 1960; Hystrichosphaeridium tubiferum (Ehrenberg) Davey and Williams, 1966; Deflandrea phosphoritica phosphoritica; Spiniferites ramosus; and $S$. cingulatus. The spore, pollen, and remanie specimens in the samples are rarer, but essentially similar to those in Core 280A-13. An upper or middle Eocene age is indicated by palynomorphs common to Cores 13 and 14.

Samples from Core 280A-15 are usually dominated either by Areosphaeridium dictyoplokus, which locally approaches $75 \%$ of the total palynoflora, or Deflandrea phosphoritica. D. cf. D. antarctica is also common. Representatives of the genus Spinidinium are rare. Other species include Aiora fenestrata and Thalassiphora pelagica. Nothofagidites matauraensis is common, and the bisaccate pollen grain Phyllocladidites mawsonii Cookson, 1947, is present together with the acritarch Leiofusa. A middle Eocene age is assigned to this core. Alisporites similis and A. grandis are both remanié elements of palynofloras from Core 15 .

Palynoflora of Core 280A-16 are similar to Core 15 and are dominated either by Areosphaeridium dictyoplokus or Deflandrea cf. D. phosphoritica. An additional form present in Core 16 is Lejeunia hyalina, a European middle to upper Eocene and Oligocene form. This core is considered to be middle Eocene. Remanié forms were not noted in this core.

Core $280 \mathrm{~A}-17$, shows a remarkable fluctuation in the dominant dinoflagellate species throughout the various sections. The top section (17-1) is dominated by Spinidinium rotundum (60\%), with Areosphaeridium dictyoplokus also abundant (30\%). In the next section (17$2)$, the codominants are Deflandrea cf. $D$. phosphoritica and $S$. rotundum $(\sim 45 \%)$. In Section 17-3, the dominant species is $D$. cf. $D$. phosphoritica $(\sim 35 \%)$, while Thalassiphora pelagica and Spinidinium are also abundant. Section 17-4 is similar. In Section 17-5, S. rotundum is again dominant ( 50\%), whereas in Section 17-6 $D$. phosphoritica et var. are dominant (over $75 \%$ ). The fluctuation in dominant species is probably related both to environmental variation and particle-size differences, since Spinidinium is somewhat smaller than the other dominant forms. In all sections, the qualitative species list is similar, and it is only in the quantitative sense that marked differences occur. Pollen, spores, and remanié material are very rare in this core.
The core 280A-18 palynoflora is dominated by Deflandrea cf. D. antarctica, although Spinidinium rotundum, Areosphaeridium dictyoplokus, Palaeoperidinium sp., and Thalassiphora pelagica are abundant. Aiora fenestrata, Deflandrea phosphoritica, Deflandrea cf. D. phosphoritica, Cleistosphaeridium sp., and Turbiosphaera funiculata (Morgenroth) Archangelsky, 1969 are common. The latter form is restricted to the middle and upper Eocene of Europe (Morgenroth, 1966), and middle Eocene is indicated for this core. Nothofagidites matauraensis predominates in an otherwise sparse microflora and rare occurrences of Alisporites similis and $A$. grandis constitute the remanie miospore assemblage palynoflora.

The samples from Core 280A-19 show the same kind of variation in the dominant species as Core 17. Sections 1 and 2 have no particularly dominant forms, with Deflandrea cf. D. antarctica, Peridinium sp., Areosphaeridium dictyoplokus, Spinidinium rotundum, and Deflandrea asymmetrica all being fairly abundant. Section 3 is dominated by $D$. cf. $D$. antarctica, while in Section 4 the codominants are $D$. cf. $D$. antarctica and A. dictyoplokus. In Section 5, D. cf. D. antarctica, A. dictyoplokus, and Spinidinium rotundum are all abundant, while in Section 6, the dominant species is Areosphaeridium dictyoplokus. Other marine palynomorphs present in Core 19 include Aiora fenestrata; Turbiosphaera filosa; T. funicuata; Deflandrea asymmetrica; $D$. phosphoritica; $D$. cf. $D$. phosphoritica; Cleistosphaeridium sp.; "Dictyosphaeridium deflandrei" Wetzel, 1952; Palaeoperidinium spp.; Spiniferites ramosus; Hystrichosphaeridium tubiferum; Leiofusa sp.; Veryhachium sp.; and Micrhystridium sp. Pollen grains are rare, with Nothofagidites matauraensis and Triorites harrisii predominating. The assemblages indicate that lower middle Eocene strata were cored. The remanié forms Alisporites grandis and $A$. similis are once again present.

Core 280A-20 assemblages are dominated by Deflandrea cf. $D$. antarctica, with Areosphaeridium dictyoplokus, Leiofusa sp., and Spinidinium sp. abundant. Core 21 assemblages are dominated by Areosphaeridium dictyoplokus and Spinidinium sp. Additional species listed in Core 19 are also present in similar proportions in Cores 20 and 21, and lower middle Eocene is indicated down to the level of Core 21.

Core 280A-22 ( 1 sample) is dominated by Spinidinium cf. $S$. aperturum, with $D$. cf. $D$. phosphoritica and $D$. cf. $D$. antarctica also abundant. Qualitatively the core resembles the overlying cores, and the presence of cysts of the $D$. phosphoritica type indicates that the bottom core is no older than Paleocene. One probable specimen of Deflandrea denticulata Alberti, 1959 may confirm lower Eocene for the bottom core.

\section{Location Summary}

The sequence at Site 280 consists of five lithologic units, underlain by basaltic rocks. The four youngest sedimentary units are Oligocene to Pleistocene in age, and are composed of nannoplankton ooze and siliceous nannoplankton ooze. The remaining sedimentary unit, comprising Cores $280 \mathrm{~A}-1$ to -22 is composed 
predominantly of Oligocene diatom ooze, clays, and silts, underlain by Eocene clay. The clay is locally glauconitic, cherty, and manganese micronodulebearing.

The palynofloras from Core 280-1 and the probable Oligocene (Cores 280A-1 to -9) covering those parts of the sequence in which oozes are developed, yielded a few contemporaneous specimens, mostly pollen grains, and a significant number of remanié specimens of species which have ranges terminating in the Lower Cretaceous or earlier. This situation appears to reflect a severe reduction in, or lack of precipitation and preservation of, marine microplankton under open oceanic conditions generally indicated by the development of oozes. However, it also shows that the terrigenous material is a component of the sediments involved, and was derived at least partially from Lower Cretaceous beds. The underlying beds are all of Eocene age, and are here subdivided into upper Eocene (Cores 10-14), middle Eocene (Cores 15-21), and lower Eocene (Core 22). Nonmarine taxa, though never prolific, become progressively less important downwards through this sequence; both the remanié and contemporaneous terrestrial palynomorphs being increasingly overwhelmed by the dinoflagellate population. The general lack of terrestrially derived material indicates that the location remained remote from terrigenous sources of sediment. In the authors' opinion, the microplankton sequence reflects a steady increase in water depths and establishment of open oceanic conditions through the sequence from the early Eocene, the greatest diversity of marine palynomorphs occurring in shallow, restricted conditions. Remanié and contemporaneous terrestrial specimens are present, but are less dominant than the dinoflagellates which are produced under more optimum conditions. The predominance of Lower Cretaceous or older nonmarine palynomorphs in the remanié assemblages indicates that terrigenous material was derived from sediments of that age. This material is an important component of the sediments of this section.

\section{SITE 281}

Preparations from Core 281-2 are barren.

Core 281-3 yielded common Deflandrea cf. D. leptodermata and, less frequently, (?)Samlandia and the pollen grains Podocarpidites ellipticus Cookson, 1947, and Triorites harrisii, the last named form having an Upper Cretaceous to Pliocene range.

Cores $281-4,-5$ and -8 were not studied.

Core 281-6 yielded a single specimen of the acritarch Leiosphaeridia telmatica; Core 7, a single Deflandrea sp.; and Core 10 several specimens of (?)Samlandia; none of which are stratigraphically significant.

The palynofloras from Core 281-11 are dominated by pollen grains with Nothofagidites cranwellae Couper, 1960 and Triorites harrisii being most common. Liliacidites sp. and Myrtaceidites parvus Cookson and Pike, 1954 are also present. The spores Laevigatosporites ovatus Wilson and Webster, 1946 (possibly remanié); Dicksonia sp.; and Cyathidites minor Couper, 1953 occur in small numbers, as does Deflandrea cf. D. leptodermata.
Cores 12 and 13 are barren.

Core 281-14 yielded occasional pollen grains, spores, and dinoflagellates. The pollen grains Nothofagidites matauraensis, $N$. flemingii, and Triorites harrisii are present, as are the saccate pollen grains Podocarpidites ellipticus and Phyllocladites sp. Dinoflagellates include Deflandrea phosphoritica; Spinidinium aperturum; $S$. rotundum; Leptodinium dispertitum; and Palmnickia lobifera Eisenack, 1954. The presence of $N$. flemingii and Palmnickia lobifera of middle and upper Eocene and Eocene ages, respectively (Couper, 1953; Eisenack, 1954), indicates that the sample is middle and upper Eocene.

Palynofloras from Core 281-15 include occasional specimens of Deflandrea phosphoritica and Leptodinium victorianum. Core 16 yielded the dinoflagellates Achomosphaera ramulifera (Deflandre) Evitt, 1963; Oligosphaeridium complex (White) Davey and Williams, 1966; and the spores Gleicheniidites senonicus Ross, 1944, and Cyathidites minor. None of these forms is of stratigraphic value in this part of the Tertiary.

Core 281-17 yielded more prolific assemblages including the dinoflagellates Deflandrea phosphoritica, $D$. cf. D. leptodermata, D. asymmetrica, Areosphaeridium dictyoplokus, and Lejeunia hyalina, and acritarch Leiosphaeridia telmatica. The pollen grain Araucariacites australis Cookson, 1947, and the spore Cyathidites minor are also common. A remanié grain of the last named species, as well as a specimen of Veryhachium reductum occur in the palynoflora. The presence of L. hyalina indicates that the palynofloras are no older than middle Eocene in age.

No deeper material from this site was examined, and the samples from Hole 281A are barren.

\section{Location Summary}

The sedimentary sequence of Site 281 is composed of four lithological units. The youngest of these is an early Miocene to Pleistocene calcareous ooze and glauconitic sand, which comprises about $60 \%$ of the section cored (Cores 1-12). The remaining units are a biogenic-rich glauconitic sand, glauconitic sand, and (?) schist breccia.

Palynofloras from the youngest unit are generally extremely sparse or barren and chronologically indeterminate. The exceptions are Core 3 , which yielded a number of dinoflagellate specimens, and Core 11, which included a predominance of terrestrial forms, indicating a temporary influx of terrigenous material.

Core 14 from the sandy section is middle and upper Eocene, and Core 17 from the breccia zone is no older than middle Eocene.

The populations of Cores 14 and 15 are relatively limited with a mixture of dinoflagellates, spores, and pollen grains, indicating marine sedimentation with some terrigenous influence. Palynofloras from the oldest core (Core 17) are similar, though slightly more diverse. The relative lack of remanie material in these assemblages possibly indicates that the sediment source for this sequence was primarily from highly compacted or metamorphic rocks, such as those cored at the base of the hole. 


\section{SITE 282}

Core 282-1 yielded occasional specimens of the pollen Myrtaceidites and the long-ranging spore Cyathidites australis. Core 4 palynofloras are locally dominated by the dinoflagellate Hystrichokolpoma rigaudae Deflandre and Cookson, 1955. Other dinoflagellates present here included Operculodinium sp.; Spiniferites cingulatus; and Cleistosphaeridium polytrichium (Valensi) Davey, Downie, Sarjeant, and Williams, 1966. Pollen grains noted include Triorites harrisii, Nothofagidites matauraensis, and Proteacidites franktonensis Couper, 1960. H. rigaudae was described from Miocene or older strata of Victoria, and $N$. matauraensis tops in the Miocene of New Zealand (Couper, 1960). P. franktonensis was described from New Zealand Miocene strata (Couper, 1960). Miocene age is indicated for Core 4. A striate saccate grain was also encountered.

Core 282-5 assemblages include the dinoflagellates Lingulodinium machaerophorum (Deflandre and Cookson) Wall, 1967; Cleistosphaeridium polytrichium; Spiniferites ramosus; $S$. cingulatus; Deflandrea phosphoritica; Hystrichokolpoma rigaudae; and Tectatodinium. Pollen grain microflora are dominated by Nothofagidites matauraensis, $N$. cranwellae, Triorites harrisii, and Myrtaceidites parvus. Proteacidites franktonensis, Triorites scaboratus Couper, 1960, as well as Plicifera delicata and other spores, are present. The overlap of Miocene pollen such as $N$. cranwellae and $P$. franktonensis with the Oligocene and older dinoflagellate $D$. phosphoritica, indicates that the core is close to the Oligocene-Miocene boundary.

Samples of Core 282-6 yielded palynofloras similar to those of Core 5.

The palynofloras of Core 282-7 include few dinoflagellates with Leptodinium victorianum, Hystrichokolpoma ragaudae, and L. machaerophorum being represented. An extensive pollen assemblage including Nothofagidites matauraensis; Triorites harrisii, Proteacidites annularis Cookson, 1950; Myrtaceidites parvus; as well as the saccate grains Dacrydiamites sp. and Microcachryidites antarcticus Cookson, 1947, is developed in these palynofloras. Of these palynomorphs, $P$. annularis and $M$. antarcticus are known only from lower Oligocene and older strata, indicating that Core 7 is no younger. Numerous remanié taxa including Foraminisporis asymmetricus (Cookson and Dettmann) Dettmann, 1963; $F$. dailyi (Cookson and Dettman) Dettman, 1963; Stereisporites antiquasporites; and Zonalapollenites trilobatus Balme, 1957, are also represented. These species all terminate their ranges in the Lower Cretaceous of Australia (Dettmann, 1963), the first two being confined to that period.

Cores $282-8$ and -9 yielded palynofloras which are as diverse as those of Core 7, and similarly composed. Additional species include the pollen grain Proteacidites clintonensis Harris, 1966 and pollen of Dacrydiumites $\mathrm{cf}$. Dacrydium cupressinum, and the dinoflagellate Deflandrea cf. D. phosphoritica. Dominance is usually maintained by $N$. matauraensis and/or $M$. parvus, but in samples of Section 282-9-2, Hystrichokolpoma rigaudae is abundant, comprising about $60 \%$ of the total palynofloras. Lower Oligocene is indicated for Cores 8 and 9. Similar remanié assemblages occur in these cores, and include monosaccate forms comparable to Nuskoisporites, and Lycopodiumsporites austroclavatidites, Coronatispora perforata Dettmann, 1963, as well as the dinoflagellate Dingodinium cerviculum Cookson and Eisenack, 1960. Both C. perforata and D. cerviculum terminate their ranges in the Lower Cretaceous, the latter form being confined to that interval (Dettmann, 1963; Haskell, 1969).

Cores 282-11 and -12 yielded diverse palynofloras dominated by miospores. Dinoflagellates include Achomosphaera cf. A. triangularis Gerlach, 1961; Deflandrea phosphritica; Hystrichokolpoma rigaudae; Spiniferites ramosus; $S$. bulloides (Deflandre and Cookson) Sarjeant, 1970; Oligosphaeridium comples; Leptodinium dispertitum; and $L$. victorianum. The Eocene-(?)Oligocene dinoflagellate Deflandrea macmurdoensis Wilson, 1967 is present in Core 12. The pollen assemblages are once again dominated by Nothofagidites cf. N. spinosus Couper, 1960; Haloragacidites cf. H. myriophylloides; Proteacidites annularis; $P$. crassus Cookson, 1950; P. parvus Cookson, 1950; P. subscabratus; P. clintonensis; and Triorites cf. T. fragilis, Couper, 1953. Saccate pollen grains include Microcachrydites antarcticus and Trisaccites microsaccatus (Couper) Couper, 1960. The joint occurrence of $P$. clintonensis, D. macmurdoensis, and Achomosphaera cf. A. triangularis in Core 12 indicates that the sediments of that core are probably of Oligocene age. Extensively reworked Mesozoic and upper Paleozoic palynofloras similar to those encountered in Cores 8 and 9 are also present in these cores.

Core 282-13 palynofloras are also dominated by terrestrial species. The dinoflagellate population includes Hystrichokolpoma rigaudae; Deflandrea phosphoritica; D. leptodermata; D. heterophlycta Deflandrea and Cookson, 1955; and Spiniferites ramosus. Nothofagidites matauraensis is common in all four samples from this core, but predominates only in Section 3. The remaining pollen forms present in Cores 11 and 12 are also present here, with the exception of Proteacidites clintonensis, but including Nothofagidites flemingii; Tricolpites asperimaginatus McIntyre, 1968, usually a Paleocene (Teurian) form (McIntyre, 1968); Beaupreaeidites elegansiformis Cookson, 1950 an Oligocene-Miocene form, although Couper (1953) reports a comparable form in the New Zealand Upper Cretaceous; and Phyllocladites mawsonii Cookson, 1947. The presence of $D$. heteroplycta, $D$. leptodermata, and $N$. flemingii in this core indicates that the Eocene has been cored at this level. Remanie forms are rare in this sample with Stereisporites antiquasporites, Lycopodiumsporites eminulus, and Alisporites similis occurring sporadically.

Palynofloras from Core 282-14 are essentially similar to those of Core 13. Additional forms included Proteacidites cf. P. retiformis Couper, 1960; Liliacidites variegatus Couper, 1953; and the dinoflagellates 
Spiniferites wetzeli and Operculodinium centrocarpum (Deflandre and Cookson) Wall, 1967.

Core 282-15 contains a typical upper Eocene dinoflagellate assemblage including Deflandrea phosphoritica and Wetzeliella glabra Cookson, 1956. This species of Wetzeliella has been recorded from the Eocene of Australia (Cookson, 1956), and upper Eocene of New Zealand (Wilson, 1967b). Other dinoflagellate species include Hystrichokolpoma cf. $H$. rigaudae, Spiniferites ramosus, Cyclonephelium sp., and Areosphaeridium dictyoplokus. Pollen is dominated by Nothofagidites, representing both the fusca and brassi types.

Cores 282-16 and -17 contain palynofloras similar to Core 15, and include the additional pollen Proteacidites subscabatus Couper, 1960 and Tricolpites striatus Couper, 1954, as well as Turbiosphaera cf. T. filosa and Nothofagidites flemingii. These cores are also upper Eocene. Rare specimens of Alisporites similis constitute the remanié assemblage in this core.

The oldest core studied (Core 282-18) from this site yielded a palynoflora with almost equal numbers of terrestrial and marine palynomorphs. The dinoflagellates in the sample include Hystrichosphaeridium recurvatum Deflandre and Cookson, 1955; Oligosphaeridium complex; Spiniferites ramosus; Deflandrea phosphoritica; $D$. cf. $D$. dartmooria Cookson and Eisenack, 1965; and Achomosphaera ramulifera. Pollen grains include Triorites harrisii, which is the most common palynomorph encountered; Proteacidites sp.; Liliacidites variegatus Couper, 1953; and Tricolpites sabulosus Dettmann and Playford, 1968. The spore Cyathidites minor is also present. The presence of $T$. harrisii and $D$. phosphoritica in this sample indicate that it is Paleocene or younger (Couper, 1960; Alberti, 1959). The occurrence of a specimen similar to $D$. dartmooria, a form which is typical of Paleocene strata, indicates a possible Paleocene age for the sample, while Tricolpites sabulosus has been reported from uppermost Cretaceous strata by Dettmann and Playford (1968). Paleocene is tentatively assigned to this core, the lastnamed occurrence being either remanié or extending the range of that form.

\section{Location Summary}

Site 282 is located west of, but relatively close to, the coast of Tasmania. The sequence intersected includes seven sedimentary units. The three youngest units are Miocene to Pleistocene calcareous oozes, which are locally glauconitic. These beds overlie lower and middle Oligocene mixed calcareous ooze and terrigenous silts and clays comprising three other lithologic units. The oldest unit, Eocene, is generally composed of silts and clays.

Based on palynological results the overall sequence is subdivided as follows: Cores 4-6 are Miocene; Cores 7-9, 11,12 are Oligocene, although Core 12 may be uppermost Eocene; Cores 13-15 are upper Eocene, Cores 16, 17 are lower Eocene, with Core 18 being Paleocene, or possibly Eocene in age.

Pollen grains predominate through much of this sequence, reflecting the continued effect of the presence of land. The localized domination of floras by Hystrichokolpoma rigaudae in parts of Cores 4 and 9 reflects some localized facies change within the marine environment, which is difficult to explain. Monosaccate remanié species representing Permo-Triassic strata, and forms which terminate their ranges in the Lower Cretaceous, indicate that the sediments cored at Site 282 were being provided, in part, by sediments from the erosion of strata of these ages from the adjacent land mass.

\section{SITE 283}

Core 283-2 yielded diverse palynofloras. Sections 2832-1 and 2-4 assemblages include the pollen grains Nothofagidites matauraensis, Nothofagidites spp., and Triorites annularis. Specimens of the dinoflagellates Deflandrea sp. and Areosphaeridium dictyoplokus are also present. Sample 2, CC yielded a moderately rich assemblage of dinoflagellate cysts and miospores. Dinoflagellate cysts are dominated by Tectatodinium sp. Other dinoflagellate species include Hemicystodinium sp; Tuberculodinium cf. T. vancampoae (Rossignol) Wall, 1967; Hystrichokolpoma rigaudae; Deflandrea phosphoritica; and a distinctive undescribed species of Palaeoperidinium. The pollen assemblage is dominated by Nothofagidites representing both the brassi and fusca types. The presence of Deflandrea phosphoritica in this core indicates that it is Oligocene or older in age.

Core 283-5 yielded diverse palynofloras. Dinoflagellates present include Deflandrea phosphoritica; $D$. macmurdoensis; D. leptodermata; D. asymmetrica; Leptodinium aculeatum Wall, 1967; and Loptodinium sp. Pollen species include Nothofagidites matauraensis; Triorites harrisii; Proteacidites grandis; $P$. crassus; $P$. parvus; Myrtaceidites parvus; Tricolpites inargutus McIntyre, 1968; the bisaccate grains Podocarpidites exiguus and Phyllocladidites sp.; and the trisaccate grain Microcachryidites antarcticus. Cyathidites minor and $C$. australis are also present. The overlap of the Oligocene form Tricolpites inargutus, and the Eocene forms Deflandrea asymmetrica and D. macmurdoensis, indicates that the sample is located adjacent to the Eocene-Oligocene boundary. The remanié species Alisporites similis is also present.

Palynofloras from Core 283-6 are essentially similar to those of Core 5 with the addition of Spinidinium aperturum, Operculodinium israelianum (Rossignol) Wall, 1967, and the pollen grains Proteacidites subscabratus and $P$. pachypolus Cookson and Pike, 1954. The latter form is known from Australian Paleocene and Eocene strata. Core 6 is considered to be Eocene, probably late Eocene in age. A remanié specimen of the Upper Jurassic and Lower Cretaceous spore Contignisporites cooksonii (Balme) Dettmann, 1963, is also present.

The palynofloras of Core 283-7 differ from preceding cores in that pollen grains occur infrequently, with Nothofagidites matauraensis, Myrtaceidites parvus, and Triorites harrissi being the most common forms encountered. The dinoflagellate assemblages are diverse and rich, the dominant species being Deflandrea cygniformis Pöthe de Baldis, 1966. Other forms present include Deflandrea phosphoritica phosphoritica, $D$. phosphoritica australis, D. leptodermata, and D. macmur- 
doensis. A middle to upper Eocene age is postulated for this sample. The remanie form Alisporites similis is also present in Core 7.

Core 283-8 samples yielded relatively limited palynofloras, usually having Deflandrea phosphoritica and/or D. cygniformis as the numerical dominant. Leptodinium victorianum, L. aculeatum, and Leptodinium sp. are also present. Occasional specimens of Triorites harrisii, Nothofagidites matauraensis, Myrtaceidites parvus, and Podocarpidites exiguus are also encountered.

Sample 283-8, CC contains a typical middle-upper Eocene dinoflagellate assemblage including Deflandrea phosphoritica and Spinidinium aperturum as codominants. Other dinoflagellate species include Leptodinium sp. (an ornate species), Deflandrea macmurdoensis, and Areosphaeridium dictyoplokus, the latter two species being common in Eocene rocks of Antarctica and South America (Wilson, 1967a; Archangelsky, 1969). Pollen species include Nothofagidites and the proteaceous species Proteacidites cf. P. grandis Cookson, 1950. This core is probably mid-upper Eocene.

The palynofloras from Core 283-9 are also of relatively low species diversity, and number of specimens. Deflandrea phosphoritica, D. cygniformis, D. leptodermata, D. heterophlycta, Leptodinium victorianum, L. dispertitum, Aiora fenestrata, and Areosphaeridium dictyplokus are usually common, with the first two species dominant. Nothofagidites matauraenus, $N$. flemingii, Triorites harrisii, Proteacidites subscabratus, and M. parvus are all present, but infrequent. A middle and upper Eocene age is indicated for the core by the presence of $N$. flemingii, and the dinoflagellate assemblage in general. Remanié species, including the Lower Cretaceous or older forms Stereisporites antiquasporites; Densoisporites velatus Weyland and Krieger, 1953; Alisporites grandis; and Neoraistrickia truncata (Cookson) Potonié, 1956 occur in these samples.

Sample 283-9, CC yielded palynoflora dominated by an undescribed species of Cladopyxidium. Other taxa include Areosphaeridium dictyoplokus; Spinidinium aperturum; Palaeoperidinium n. sp.; Schematophora sp.; Operculodinium sp.; and one probable specimen of Cassidium fragilis (Harris) Drugg, 1967. Pollen is relatively rare, and a probable middle Eocene age is indicated.

Core 283-11 yielded excellent palynoflora, all dominated either by Areosphaeridium dictyoplokus or Deflandrea phosphoritica. Other less common dinoflagellate cysts include Aiora fenestrata, Acanthaulax sp., Deflandrea cf. D. antarctica, Spinidinium aperturum, and Thalassiphora pelagica. Some excellent specimens of the characteristic middle Eocene dinoflagellate Wetzeliella echinosuturata Wilson, 1967 were found in Sample 283-11, CC. Pollen is relatively rare, but inncludes Nothofagidites matauraensis and Proteacidites subscabratus. A middle Eocene age can be assigned to this core on palynological evidence. Remanié specimens of Alisporites similis are present in these palynofloras.

Core 283-12 palynofloras contain a number of lowermost Tertiary types of Deflandrea, including $D$. cf. $D$. cooksoni; D. asymmetrica; D. speciosa Alberti, 1959; as well as $D$. phosphoritica et var. Pollen species include Gambierina edwardsii (Cookson and Pike) Harris, 1972 and Proteacidites subscabratus; as well as the bisaccate grain Podocarpidites exiguus and the trisaccate grain Trisaccites microsaccatus. D. speciosa was described from German Paleocene strata and G. edwardsii is known from middle Paleocene strata of southern Australia (Harris, 1965). A Paleocene, possibly middle Paleocene, age is indicated for this core. Remanié specimens of Alisporites grandis, A similis, and Stereisporites antiquasporites are present in these palynofloras.

Cores 283-13 to -15 (14 samples) contain fairly similar rich palynoflora and are probably all $\mathrm{Pa}$ leocene, in age, based on palynological evidence. Dinoflagellate species include Svalbardella australina Cookson, 1965; Turbiosphaera filosa; Deflandrea denticulata Alberti, 1959; Eisenackia crassitabulata Deflandre and Cookson, 1955; Acanthaulax spp.; a characteristic ornate species of Leptodinium; Palaeoperidinium cf. P. pyrophorum (Ehrenberg) Sarjeant, 1967; Membranilarnacia sp.; Cleistosphaeridium sp.; Cassidium fragilis; and Areosphaeridium dictyoplokus. The Upper Cretaceous/basal Tertiary colonial alga, Palambages morulosa Wetzel, 1933 is a rare element of these assemblages. Miospores are also rare and include the reworked Mesozoic forms Classopollis classoides; Alisporites similis; and Ceratosporites equalis Cookson and Dettmann, 1958.

Core 283-16 (4 samples) appears to be slightly older and may be lower Paleocene. Similar assemblages to those of Cores 13-15 occur with the addition of the characteristic dinoflagellates Systematophora sp. and Glyphanodinium cf. G. facetum Drugg, 1964, the latter species being previously recorded from the Paleocene of California (Drugg, 1964). Pollen includes Gambierina edwardsii, a middle Paleocene and Upper Cretaceous form (Harris, 1965; Dettmann and Playford, 1968).

Core 283-17 (6 samples) contains a mixture of uppermost Cretaceous and lower Tertiary palynomorphs, and is therefore tentatively assigned to the "CretaceousTertiary boundary". Species include the dinoflagellates Deflandrea cretacea Cookson, 1956; D. cf. D. bakeri Deflandre and Cookson, 1955; Cribroperidinium cf. C. orthoceras (Eisenack) Davey, 1967; Glyphanodinium cf. G. facetum; Cleistosphaeridium sp.; Eisenackia sp.; Areoligera cf. A. senonensis Lejeune-Carpentier, 1938; Deflandrea denticulata; and Exochosphaeridium cf. E. striolatum (Deflandre) Davey, 1969. Palambages morulosa is fairly common; pollen is rare.

Samples from Hole 283A were either barren or yielded extremely sparse assemblages.

\section{Location Summary}

Four sedimentary units were cored at Site 283, the youngest being a zeolitic claystone of unknown age. This unit is underlain by a siliceous ooze at Cores 283-2 to -6 . The remainder of the sequence is composed of silty or clayey material. Core 2 is of Oligocene age, while Core 5 is basal Oligocene or latest Eocene in age. Cores 6-9 are of upper Eocene age, and Cores 10 and 11 are 
middle Eocene. Cores 12-15 are middle or upper Paleocene, and Core 16 appears to be lower Paleocene. Core 17 is either lowermost Paleocene or uppermost Cretaceous in age.

Dinoflagellate cysts dominate the assemblages and are consistently rich both in individuals and diversity. Terrestrial pollen grains are present throughout, although these are more relatively common in younger cores, due mainly to a decrease in dinoflagellates. The continued presence of these grains probably reflects a relative "down-stream" effect of the site location with respect to the palaeocurrents developed during the time of sedimentation. The persistence of remanié Lower Cretaceous forms in this sequence is probably due to the same effects.

The diversity and dominance of palynofloras by dinoflagellates in the Eocene of this hole is not as prevalent as those of similar age cored at Site 280 . Water depths at Site 283 apparently remained at or below calcium carbonate solution level throughout the deposition of the sequence. The continued diverse dinoflagellate spectra may reflect "down-stream" effects, the plankton being derived from the Australian shelf region.

\section{SITE 284}

Site 284 is some distance from the sites discussed previously, and based on shipboard micropalaeontology, has a generally younger sediment sequence of late Miocene to Pleistocene age. Palynofloras from this sequence are different to those from the other sites examined. The species diversity of these assemblages is consistently low, and spores and pollen grains are generally very rare. The microplankton assemblages are usually composed of a small number of species which have a persistent occurrence through parts of the sequence. Few of the forms present have stratigraphic significance.

Core 284-3 to Section 284-5-1 are characterized by the occurrence of Spiniferites mirabilis (Rossignol) Sarjeant, 1970 in variable, occasionally dominant, numbers. Leptodinium dispertitum, L. aculeatum, and Spiniferites ramosus are also present in this interval. Occasional specimens of Nothofagidites sp., Triorites sp., Myrtaceidites eugeniioides, Podocarpidites exiguus, and Cyathidites australis are also encountered.

The samples of Cores 284-5 (Sections 2-6) to 9 are virtually barren, with only occasional specimens of angiosperm pollen grains, and dinoflagellates present. These include Oligosphaeridium $\mathrm{cf} . O$. complex, Triorites cf. T. harrisii, Myrtaceidites parvus, and Cyathidites minor.

Samples from Core 284-10 yielded a few spores and pollen grains including Triorites harrisii, Myrtaceidites parvus, Proteacidites sp., Podocarpidites $\mathrm{cf}$. P. ellipticus, $P$. exiguus, Cyathidites minor, and Plicifera delicata.

Cores $284-11$ to -13 yielded limited assemblages with rarely more than 10 forms each. Leptodinium dispertitum and $L$. aculeatum are the dominant palynomorph species. Other microplankton include Spiniferites ramosus, Operculodinium israelianum (one occurrence), Michrystridium spp., and Leiosphaeridia telmatica.
Pollen grains again vary in occurrence, and include those mentioned in Core 10 as well as Nothofagidites cranwellae; $N$. cf. F. canaliculatus Dettmann, 1963; and Palambages sp. is also represented. The Cretaceous spore Ceratosporites equalis Cookson and Dettmann, 1958 , is present in Core 12.

Palynofloras of Cores $284-14$ to -16 are essentially similar to those of the previous interval, although Operculodinium israelianum is common, dominating the relatively limited assemblages.

Samples of Cores 284-17 to 19 are similar to Cores 1416 above, but lack Operculodinium israelianum. A single specimen of Systematophora placacantha (Deflandre and Cookson) Davey, Downie, Sarjeant, and Williams, 1966, is present in Core 17. This form was described from the middle Miocene of Victoria, Australia.

Palynofloras from the remaining cores are similar to those above and are dominated by Leptodinium victorianum and $L$. dispertitum, these species occasionally being the only forms present. $L$. aculeatum is absent or rare.

\section{Location Summary}

The low but consistent species diversity in palynofloras from this site is related to the open-ocean conditions in this area during the deposition of the sequence. The continued occurrence of species of Loptodinium through the sequence is extremely rare, although a similar occurrence was reported by Wall (1967) from a deep-sea core in the Caribbean Sea. The general lack of nonmarine palynomorphs from this locality, which is relatively close to the New Zealand coast, is probably due to the site location being "upstream" with respect to paleocurrent directions during the late Miocene and Pliocene. Miospores present in the microflora were derived from the Australia region, and were carried to these locations by a westward-moving current.

Little stratigraphic information is available from the palynofloras of this site.

\section{GENERAL CONCLUSIONS}

At all but Site 284 the use of palynology provides a satisfactory Tertiary biostratigraphic subdivision for each sequence. Such a subdivision involves both dinoflagellates and pollen grains, which tend to complement each other, providing useful stratigraphic results.

Palynofloras from the five sites studied show considerable variation in both miospore and dinoflagellate populations, as well as in the relative numerical balance between the two groups. The presence of large numbers of pollen grains throughout the sequence cored at Site 282 indicates that the locale, though marine, remained under the influence of nonmarine waters during the Cenozoic. The sequence at Site 284 reflects remote oceanic conditions and consistently yielded small, predominantly dinoflagellate palynofloras. At the remaining sites, dinoflagellates are usually more common than nonmarine palynomorphs. The number of specimens and the species diversity varies considerably, especially within the dinoflagellates of the Paleocene of Site 283, and lower to lower-middle Eocene of Sites 280, 
281 , and 282. In comparison with consistently small oceanic dinoflagellate palynoflora of Site 284 , this change may reflect the penetration of oceanic waters into the region during the lower to lower-middle Eocene at Sites 280, 281, and 282, and Paleocene at Site 283.

The constituent species of Eocene and Oligocene dinoflagellate assemblages from Sites $280-283$ can be divided into two groups: species such as Lejeunia hyalina, Deflandrea phosphoritica, Palmnickia lobifera, and Thalassiphora pelagica which are widely known in lower Tertiary deposits in various parts of the world; and a group including Turbiosphaera filosa, Spinidinium aperturum, Deflandrea distinctum, D. macmurdoensis, $D$. asymmetrica, D. antarctica, D. cygniformis, and Wetzeliella echinosuturata, which are present, along with some or all of the above forms, in palynofloras from the Ross Sea area of Antarctica (Wilson 1967a, b), and South America (Archangelsky, 1968; Archangelsky and Fasola, 1971; Pöthe de Baldis, 1966). The abundance of Aiora fenestrata and Areosphaertidium dictyoplokus appears to be a feature of palynofloras both from the lower Tertiary of the localities studied here, and from the Ross Sea.

This similarity and the unique nature of the dinoflagellate assemblages noted here and those of similar age in Antarctica and South America indicate that some provincial controls were exerted on the distribution of these forms. If this control was only latitudinal and climatically based, it would appear that the province should include parts of Southern Australia and New Zealand. However, these characteristic dinoflagellate associations have not been recorded in these two countries. The distribution encompassing the Leg 29 sites, south of Australia and New Zealand, in addition to Antarctica, suggests a common high latitude, lower Tertiary biogeographic province about the time of, or soon after, the separation of the Antarctic and Australian continents. The presence of the same assemblages in South America, including Tierra del Fuego, indicate that the same province extended to the southernmost South American area, and may have been related to early stages in the development of the CircumAntarctic current.

Remanié assemblages from the sites studied include a distinctive Permian and Triassic suite consisting of monosaccate and striate bisaccate grains and a Lower Cretaceous suite of saccate pollen grains, spores, and a single dinoflagellate species. These types of remanié palynofloras are well known in Antarctic and Australian Tertiary palynofloras (Wilson, 1968; Harris, 1965). Permian and Triassic sediments are widespread in Antarctica, Australia, and New Zealand, although in the last case the metamorphic grades of such strata is usually, though not invariably, too high for preservation of microfossils. The presence of Permian and Triassic remanie microfossils in the sequences studied reflects a contribution of Permian and Triassic age to the sediments from the Australian and Antarctic continents in the initial stages of separation, and probably from Australia as separation increased.

The presence of a Lower Cretaceous remanié palynoflora indicates that the Australian continental mass had a strong influence on sedimentation. Cretaceous sediments are now uncommon on the Antarctic continent, and were possibly never extensively developed there. In Australia, on the other hand, very large areas are underlain by Lower Cretaceous strata (Dettmann, 1963; Whitehouse, 1955). In southeastern Australia these strata are predominantly nonmarine (Dettmann, 1963; Haskell, 1972) although late Aptian and Albian marine sediments in the Great Artesian Basin are widespread north and west of the areas of nonmarine beds.

The nonmarine nature of the Lower Cretaceous remanié assemblages, shows that southeastern Australia clearly contributed extensively to the sediments of the sequences at Sites 280-283, although the occurrence of a single marine Lower Cretaceous specimen suggests that the Great Artesian Basin was also a source of terrigenous sediment.

\section{ACKNOWLEDGMENTS}

The authors gratefully acknowledge the technical assistance given by the New Zealand Geological Survey, the Eastern Petroleum Section of the Geological Survey of Canada, and Robertson Research (North America) Ltd. during all phases of this study. Special thanks are due to Dr. Jon Bujak of Robertson Research for discussion of results, Miss Shiela Clyburne of the Eastern Petroleum Section for quick and excellent work on preparations, and Mrs. Juliette Murphy who typed the manuscript through its several stages.

\section{REFERENCES}

Alberti, G., 1959. Zur Kenntnis der Gattung Deflandrea Eisenack (Dinoflag.) in der Kreide und in Alttertiär Nord und Mittleldeutschlands: Mitt. Geol. Staatsinst. Hamburg, v. 28 , p. $93-105$.

Archangelsky, S., 1968. Sobre el paleomicroplancton del Tertiario inferior de Rio Turbio, provincia de Santa Cruz: Ameghiniana, v. 5, p. 406-416.

1969. Estudio del paleomicroplancton de la Formacion Rio Turbio (Eoceno), Provincia de Santa Cruz: Ameghiniana, v. 6, p. 181-218.

Archangelsky, S. and Fasola, A., 1971. Algunos elementos del paleomico-plancton del Tertiario Inferior de Patagonia (Argentina y Chile): Rev. Mus. La Plata, Sec. Paleont., n.s. v. 6, p. $1-18$.

Balme, B. E., 1957. Spores and pollen grains from the Mesozoic of Western Australia: Comm. Sci. Ind. Res. Org. Coal Res. Sec., v. 25 , p. 1-48.

Bujak, J. P., in press. Microplankton from the Barton Beds, upper Eocene, of southern England: Palaeontographica.

Cookson, I. C., 1956. Additional microplankton from Australian la-e Mesozoic and Tertiary sediments: Australian J. Mar. Freshwat. Res. v. 7, p. 183-191.

Cookson, I. C. and Dettmann, M. E., 1958. Some trilete spores from upper Mesozoic deposits in the eastern Australian region: Roy. Soc. Victoria Proc., v. 70, p. 95128.

Couper, R. A., 1953. Upper Mesozoic and Cainozoic spores and pollen grains from New Zealand: New Zealand Geol. Surv. Paleontol. Bull., v. 22, p. 1-77.

1960. New Zealand Mesozoic and Cainozoic plant microfossils: New Zealand Geol. Surv. Paleontol. Bull., v. 32 , p. $1-87$.

Dettmann, M. E., 1963. Upper Mesozoic microfloras from southeastern Australia: Roy. Soc. Victoria Proc., v. 77, p. $1-148$. 
Dettmann, M. E. and Playford, G., 1968. Taxonomy of some Cretaceous spores and pollen grains from eastern Australia: Roy. Soc. Victoria Proc., v. 81, p. 69-94.

Drugg, W. S., 1964. Glyphanodinium, a new Dinoflagellate genus from the Paleocene of California: Bio. Soc. Washington Proc., v. 77, p. 237-240.

Eisenack, 1954. Mikrofossilieu aus Phosphoriten des samländischen Unteroligozäns und uber de Einheitliekhert der Hystrichosphaerideen: Palaeontographica, v. 105B, p. 4995.

Evans, P. R., 1966. Mesozoic stratigraphic palynology in Australia: Australian Oil Gas J., v. 12, p. 58-63.

Gerlach, E., 1961. Mikrofossilien aus dem Oligozan und Miozan Nordwestdeutschands, unter besonderer Berucksichtigung der Hystrichospharen und Dinoflagellaten. Neues Jahrb Geol. Palaontol., Abh., v. 112 , p. $143-228$.

Harris, W. K., 1965. Basal Tertiary microfloras from the Princetown area, Victoria, Australia: Palaeontographica, v. 115B, p. 75-106.

Haskell, T. R., 1968. Saccate pollen grains from the Lower Cretaceous of the Great Artesian Basin, Australia: University of Queensland, Dept. Geol. Paper, 6(8): 211-43.

1969. Dinoflagellate species Dingodinium cerviculum, Odontochitina operculata, and Muderongia tetracantha in Lower Cretaceous strata of the Great Artesian Basin Australia: Roy. Soc. Queensld. Proc., v. 81 p. $57-68$.

1972. Hydrocarbon potential of the Mesozoic and basal Tertiary of the Gippsland Basin: A stratigraphic analysis: Australian Petrol. Expl. Assoc. J. v. 12 (1) p. 138143.

McIntyre, D. J., 1968. Further new pollen species from New Zealand Tertiary and uppermost Cretaceous deposits: New Zealand J. Bot., v. 5, p. 469-497.

Morgenroth, P., 1966. Mikrofossilien und konkretionen des Nordwest europäischen Untereozöan. Palaeontographica, v. 1 p. $1-53$.

Playford, G. and Dettmann, M. E., 1965. Rhaetic-Liassic plant microfossils from the Leigh Creek Coal Measures, South Australia: Senckenb. Lethaia, v. 46(2-3), p. 127-181.

Pöthe de., Baldis, E. D., 1966. Microplancton del Tertiario de Tierra del Fuego: Ameghiniana, v. 4, p. 219-226.

Wall, D., 1967. Fossil microplankton in deep-sea cores from the Caribbean Sea: Paleontology, v. 10, p. 95-123.

Whitehouse, F. W., 1955. The geology of the Queensland portion of the Great Artesian Basin. Appendix G. Artesian Water Supplies in Queensland. Dep. Co-ord. Gen. Pub. Works., Od. 1954: 1-20.

Wilson, G. J., 1967a. Some new species of lower Tertiary dinoflagellates from McMurdo Sound, Antarctica: New Zealand J. Bot., v. 5, p. 57-83.

1967b. Some species of Wetzeliella Eisenack (Dinophyceae) from New Zealand Eocene and Paleocene strata: New Zealand J. Bot., v. 5, p. 469-497.

1968. On the occurrence of fossil microspores, pollen grains, and Microplankton in bottom sediments of the Ross Sea, Antarctica. New Zealand J. Mar. Freshwat. Res. v. 2, p. 381-389. 



\section{PLATE 1}

Selected Palynomorphs from Sites 280-284

(Magnification values only approximate)

Figure $1 \quad$ Areosphaeridium dictyoplokus (Klumpp). Sample 283-11A, CC; L6422; ×640

Figure 2 Wetzeliella (Wetzeliella) echinosuturata Wilson. Sample 283-11, CC; L6422/1; ×400.

Figure 3 Deflandrea cretacea Cookson. Sample 283-17-4, 14 $\mathrm{cm} ; \mathrm{L} 6462 / 1 ; \times 640$.

Figure $4 \quad$ Deflandrea phosphoritica Eisenack. Sample 283-7, CC; L6439/1; ×500.

Figure 5 Deflandrea aff. bakeri Deflandre and Cookson. Sample 283-17-1, $40 \mathrm{~cm}$; L6359/4; $\times 400$.

Figure 6 Spinidinium aperturum Wilson. Sample 280A-14-2, $57 \mathrm{~cm} ; \mathrm{L} 6389 / 1 ; \times 800$.

Figure 7 Deflandrea asymmetrica Wilson. Sample 281-14-1, $120 \mathrm{~cm}$; L6458/2; $\times 500$.

Figure $8 \quad$ Nothofagidites matauraensis (Couper). Sample 283-4, CC; L6353/2; ×800.

Figure 9 Triorites harrisii Couper. Sample 283-2, CC; L6436/2; ×800.

Figure $10 \quad$ Proteacidites sp. Sample 283-13-5, $64 \mathrm{~cm}$; $\mathrm{L} 6447 / 2 ; \times 800$.

Figure $11 \quad$ Gambierina edwardsii (Cookson and Pike). Sample 281-14-1, $120 \mathrm{~cm} ; \mathrm{L} 6458 / 2 ; \times 800$.

Figure 12 Deflandrea antarctica Wilson. Sample 280A-20-3, $38 \mathrm{~cm}$; L6370/2; $\times 640$.

Figure 13 Deflandrea macmurdoensis Wilson. Sample 280A10-5, $66 \mathrm{~cm}$; L6399/1; $\times 640$.

Figure 14 Deflandrea cygniformis Pöthe de Baldis. Sample 283-7, CC; L6439/1; ×320.

Figure 15 Svalbardella australina Cookson. Sample 283-13-4, $38 \mathrm{~cm}$; L6446/1; $\times 300$. 
PLATE 1

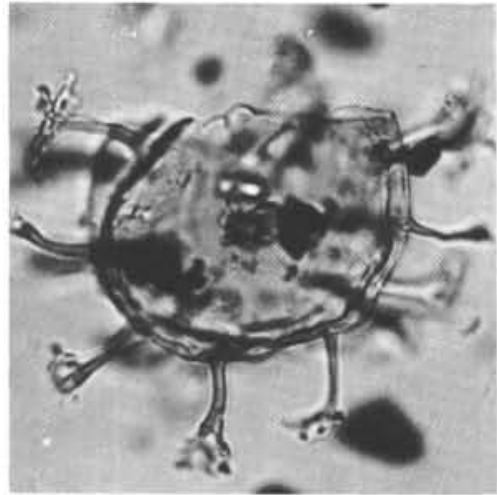

1

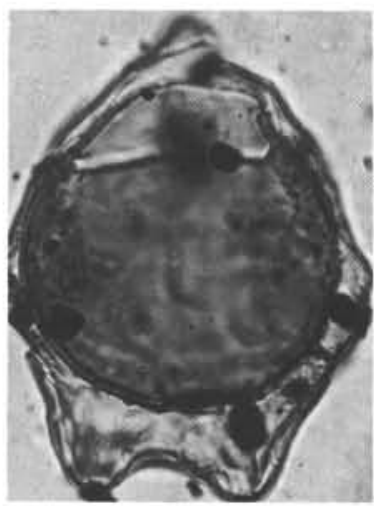

4

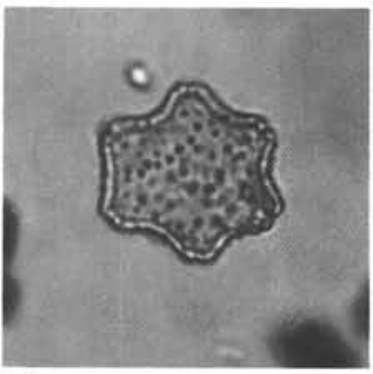

8

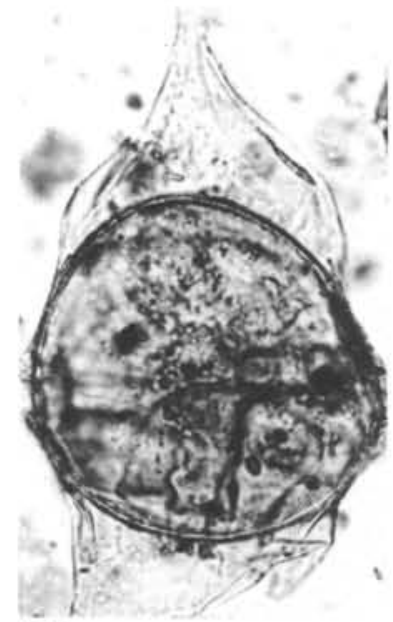

12

13

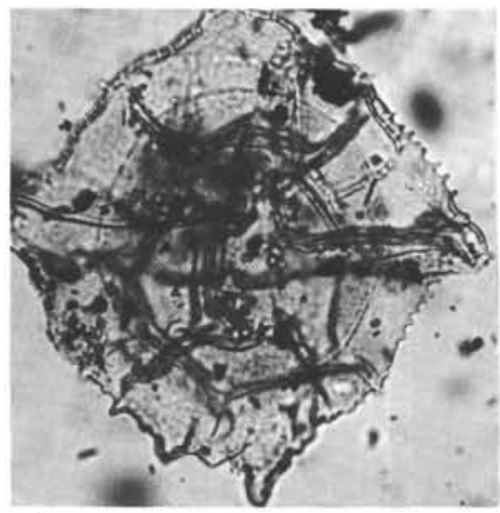

2
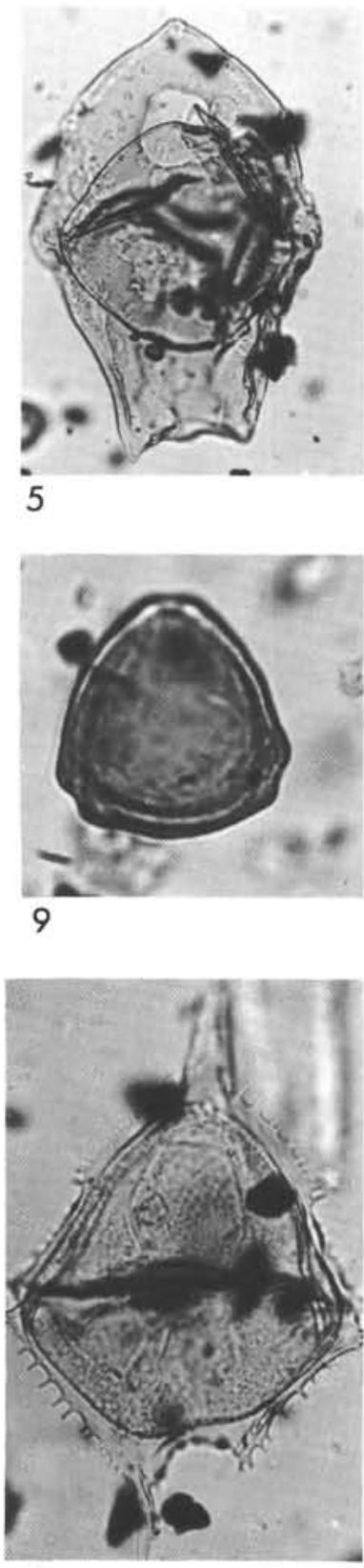
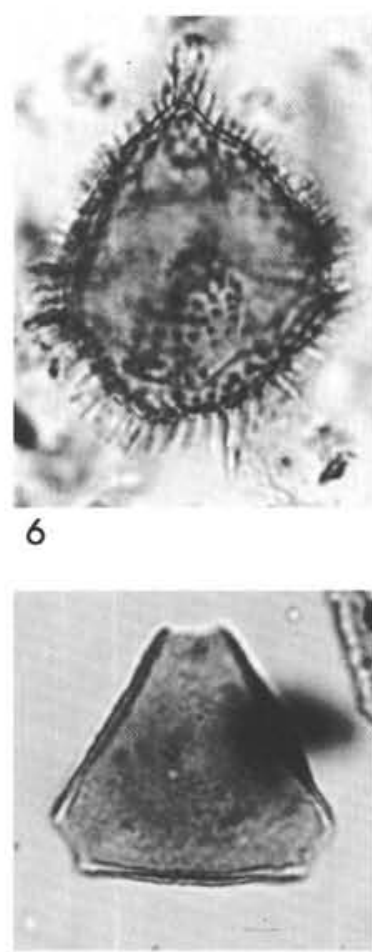

10

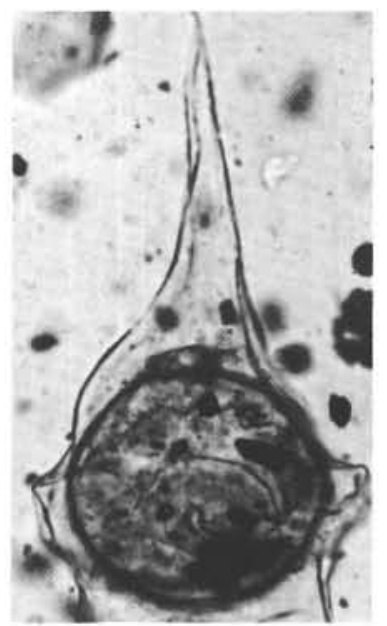

14

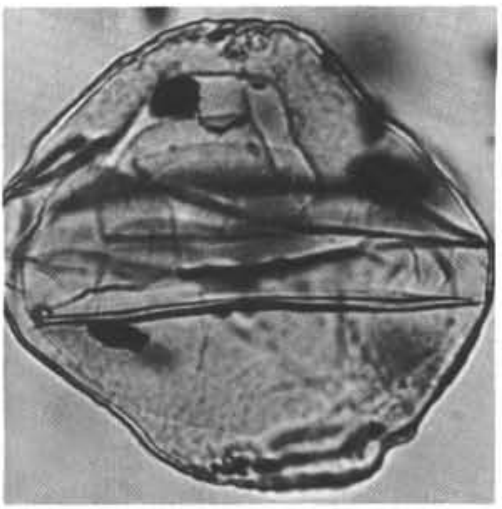

3
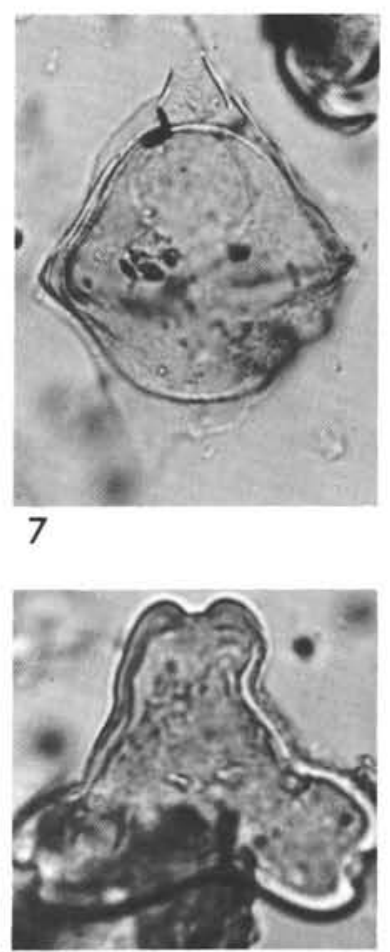

11

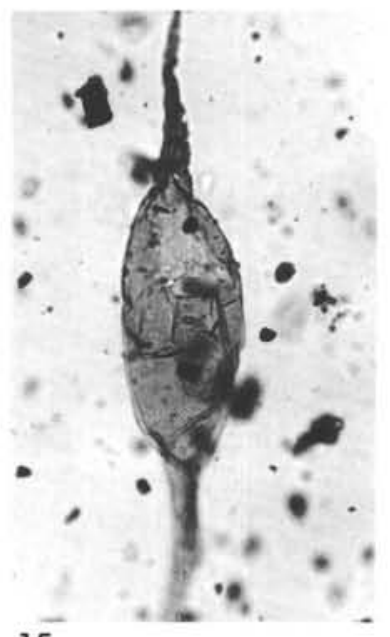

15 


\section{PLATE 2}

Selected Palynomorphs from DSDP Sites 280-284

(Magnification values only approximate)

Figures 1, 2, $7 \quad$ Leptodinium $\mathrm{sp} . \times 640$.

1. Sample 283-15-2, $38 \mathrm{~cm}$; L6490/1.

2. Sample 283-13-2, $15 \mathrm{~cm} ; \mathrm{L} 6444 / 2$.

7. Sample 283-7, CC; L6439/1.

Figure 3 Dictyosphaeridium deflandrei W. Wetzel. Sample 283-13-2, $15 \mathrm{~cm}$; L6444/2; $\times 800$.

Figure 4 Aiora fenestrata (Deflandre and Cookson). Sample 283-11, CC; L6422; $\times 500$.

Figure 5 Thalassiphora pelagica (Eisenack). Sample 280A18-1, $117 \mathrm{~cm} ; \mathrm{L6380/1; \times 300.}$

Figure 6 Tectatodinium sp. Sample 283-2, CC; L6436/1; $\times 800$.

Figure $8 \quad$ Palaeoperidinium sp. Sample 283-2, CC; L6436/2; $\times 800$.

Figure 9 Palambages morulosa O. Wetzel. Sample 283-17-1, $40 \mathrm{~cm}$; L6359/4; $\times 640$.

Figure 10 Turbiosphaera sp. cf. T. filosa (Wilson). Sample 280A,-17, CC; L6380/1; ×640.

Figure 11 Palaeoperidinium pyrophorum (Ehrenberg). Sample 283-14-4, $70 \mathrm{~cm}$; L6489/1; ×500.

Figure 12 Hystrichokolpoma rigaudae Deflandre and Cookson. Sample 283-8, CC; L6354/2; ×640. 
PLATE 2
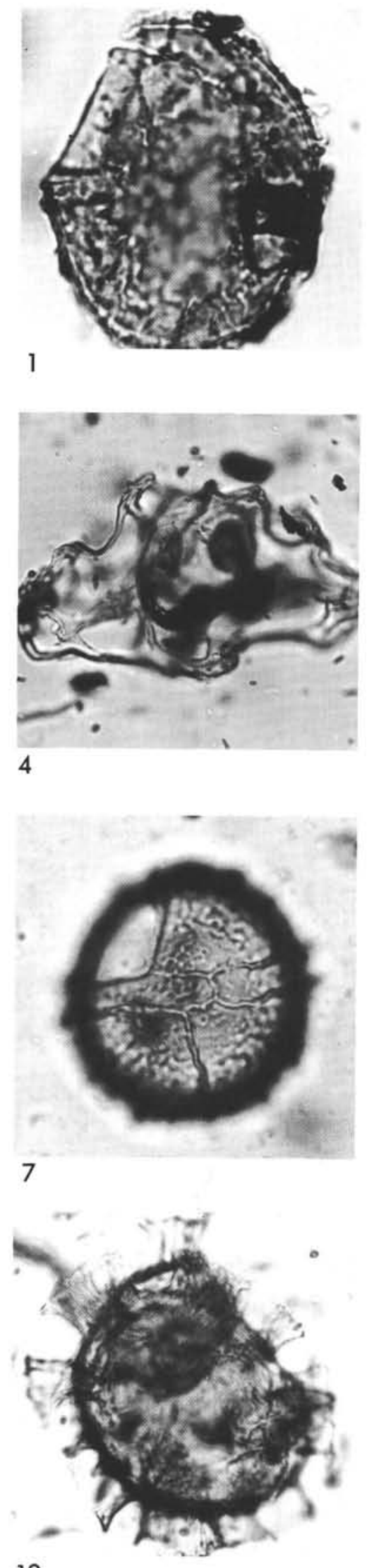

10
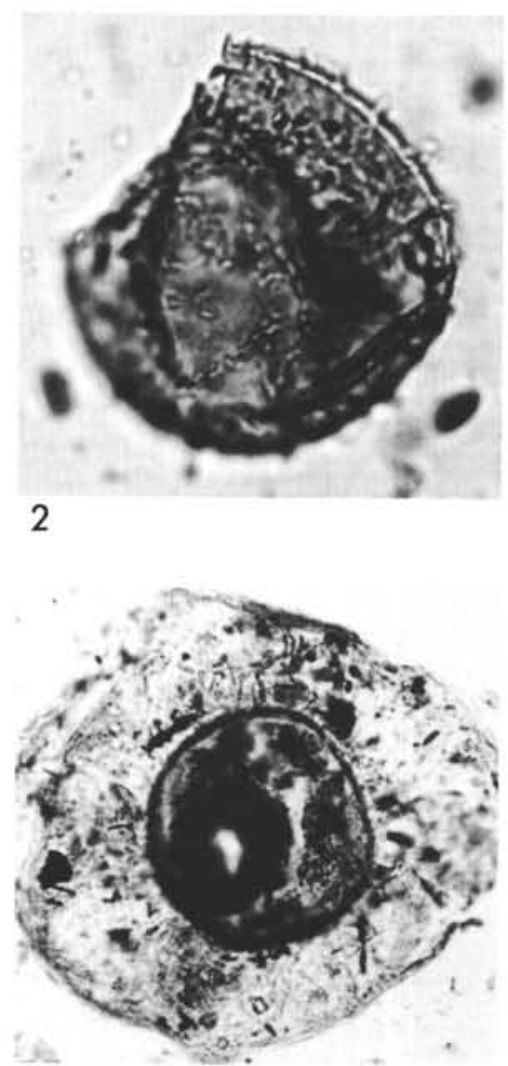

5

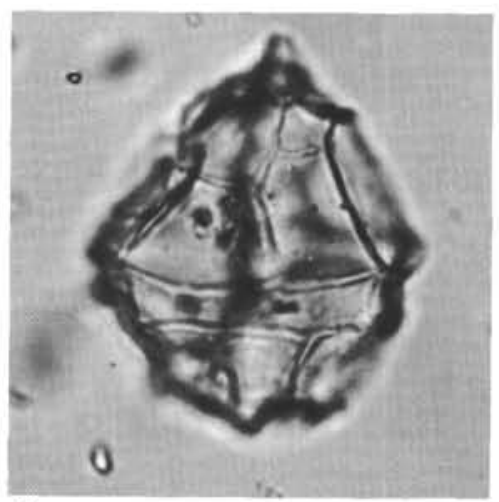

8

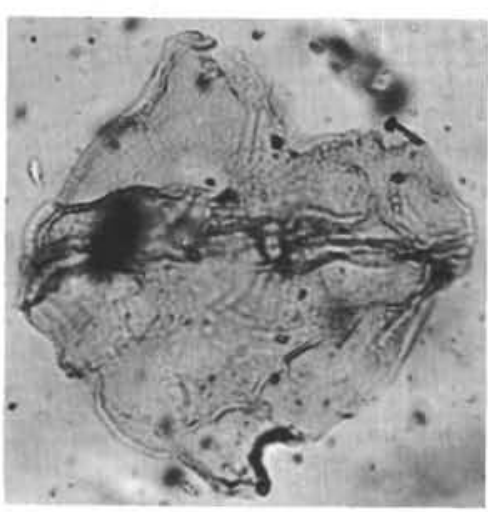

11
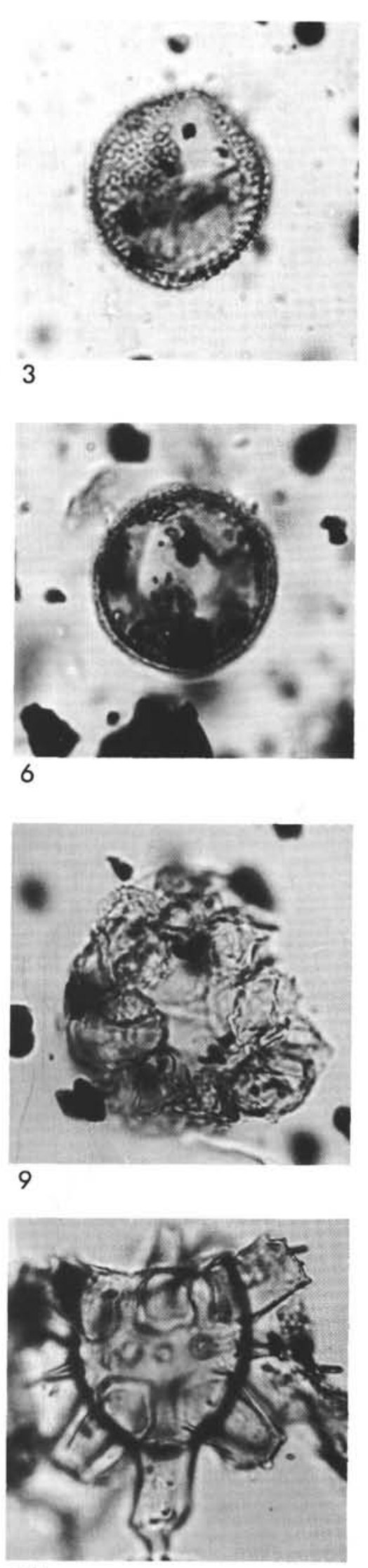

12 


\section{PLATE 3}

Selected Palynomorphs from DSDP Sites 280-284

(Figures 1-9, $\times 500$; Figures 10-15, $\times 750$ )

Figure 1 Leptodinium victorianum Cookson and Eisenack. Sample 284-19-2, $80 \mathrm{~cm}$; P3460-01.

Figure 2 Lejeunia hyalina Gerlach. Sample 282-16-1, $90 \mathrm{~cm}$; P3321-01.

Figure 3 Cassidium fragilis (Harris). Sample 282-14-3, 70 cm; P3320-01.

Figure 4 Operculodinium israelianum (Rossignol). Sample 284-15-3, $80 \mathrm{~cm}$; P3439-01.

Figure 5 Eisenackia crassitabulata Deflandre and Cookson. Sample 283-14-2, $70 \mathrm{~cm}$; P3356-01.

Figure 6 Leptodinium dispertitum Cookson and Eisenack. Sample 283-14-2, $81 \mathrm{~cm}$; P3356-01.

Figure 7 Systematophora placacantha Deflandre and Cookson. Sample 284-17-2, $92 \mathrm{~cm}$; P3449-01.

Figure $8 \quad$ Deflandrea heterophlycta Deflandre and Cookson. Sample 282-9-3, $60 \mathrm{~cm}$; P3307-01.

Figure 9 Dingodinium cerviculum Cookson and Eisenack. Sample 282-8-2, $87 \mathrm{~cm}$; P3302-01.

Figure $10 \quad$ Phyllocladidites mawsonii Cookson. Sample 28213-3, $70 \mathrm{~cm}$; P3316-01.

Figure 11 Cicatricosisporites australiensis (Cookson). Sample 283-9-5, $90 \mathrm{~cm}$; P3347-01.

Figure 12 Cyathidites minor Couper. Sample 282-13-3; P3316-02.

Figure 13 Dacrydiumites. Sample 282A-13-3, $70 \mathrm{~cm}$; P331601 .

Figure 14 Podocarpidites exiguus Harris. Sample 284-19-1, $95 \mathrm{~cm}$; P3459-01.

Figure 15 Podocarpidites ellipticus Cookson. Sample 284-20$6,80 \mathrm{~cm}$; P3470-01. 
PLATE 3

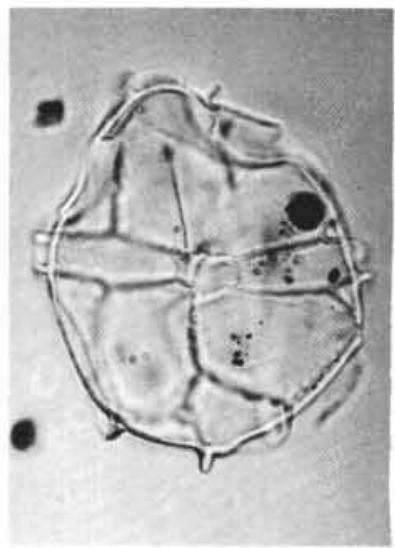

1
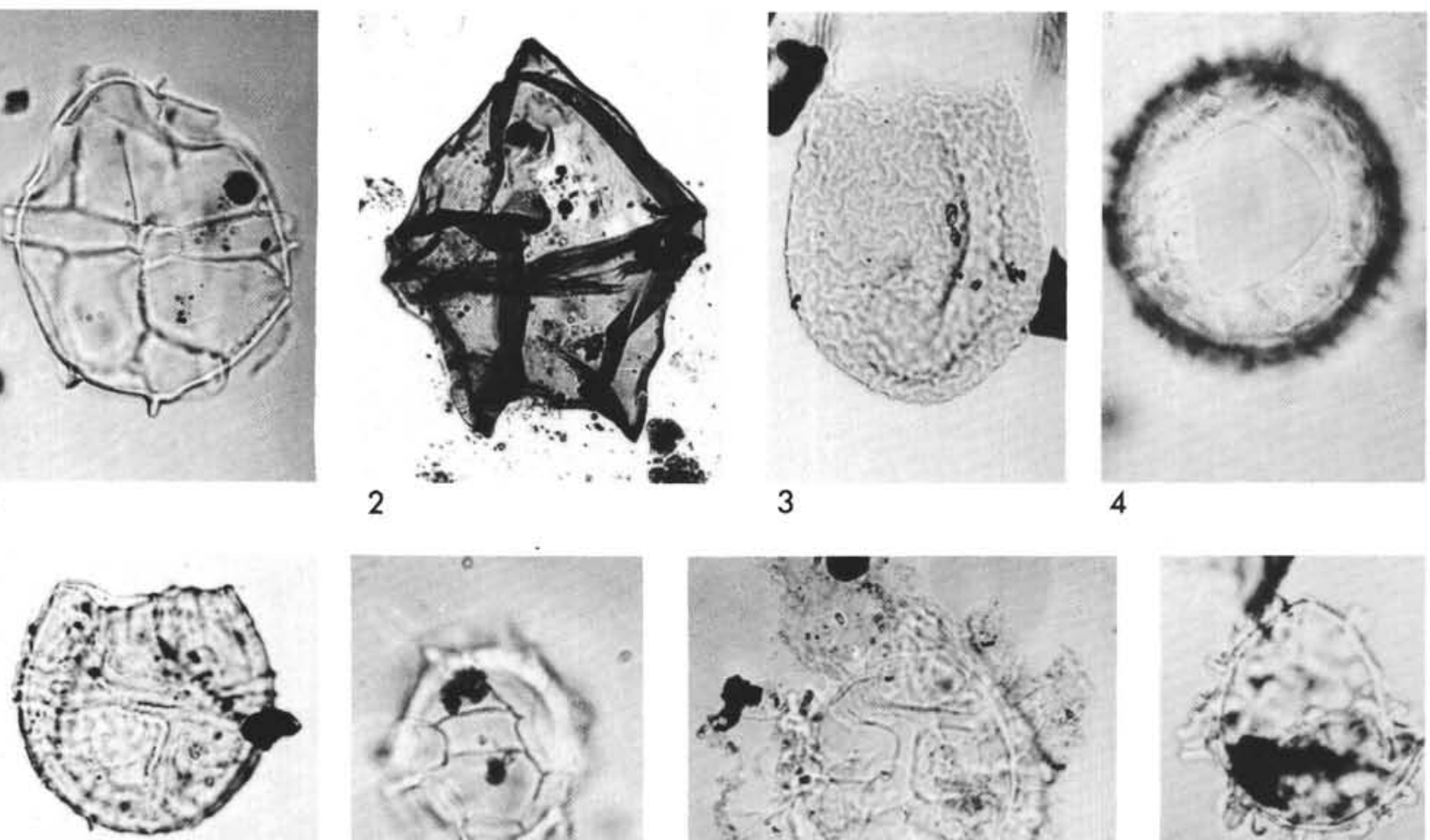

5
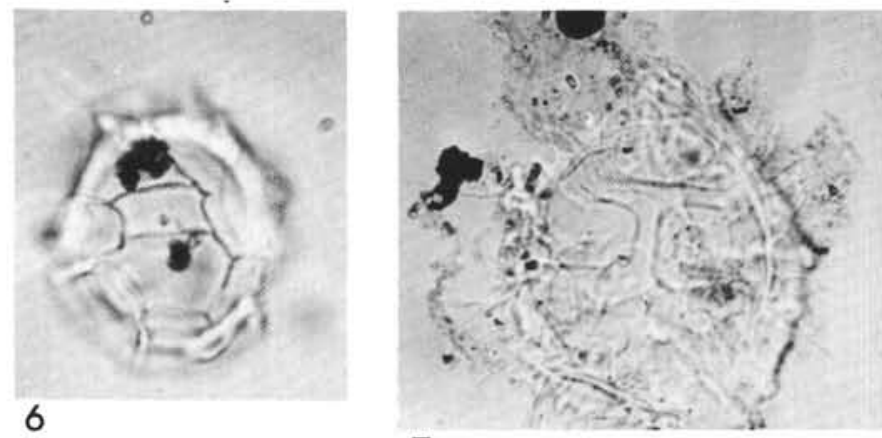

7
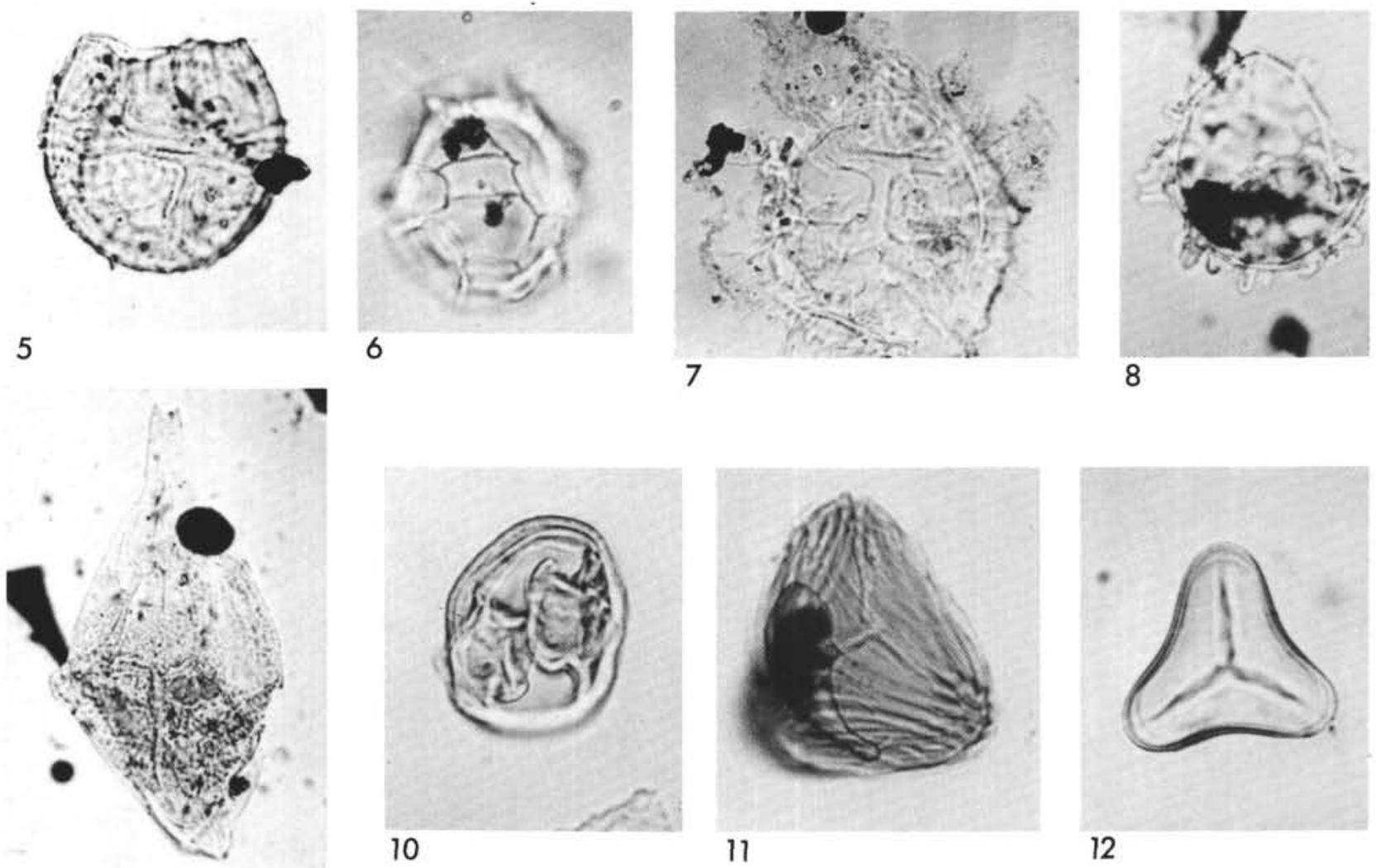

11

12

9
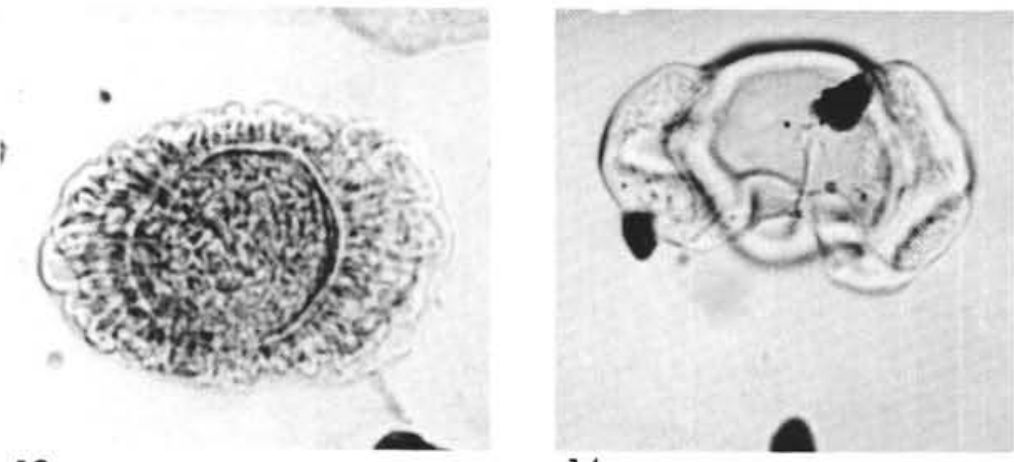

14

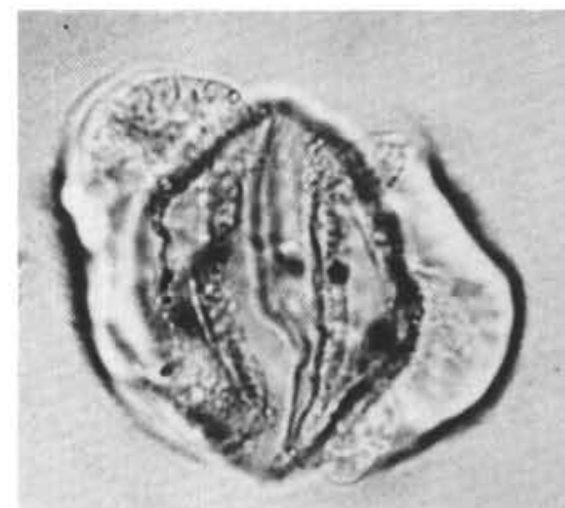

15 


\section{PLATE 4}

Selected Palynomorphs from DSDP Sites 280-284

(Figures 1-15, $\times 750$; Figures 16-22, $\times 500$ )

Figure 1 Beaupreaeidites eleganisformis Cookson, Sample 282-13-3, $70 \mathrm{~cm}, \mathrm{P} 3314-02$.

Figures 2,3 Proteacidites annularis Cookson.

2. Sample 282-4-3, $70 \mathrm{~cm} ; \mathrm{P} 3298-01$.

3. Sample 282-13-3, $67 \mathrm{~cm}$; P3316-02.

Figures 4,5 Tricolpites sabulosus Dettman and Playford. Sample 282-18-1, $85 \mathrm{~cm}$; P3328-01.

4. General View.

5. Detail of colpae.

Figure 6 Proteacidites incurvatus Cookson. Sample 283-9-3, $90 \mathrm{~cm}$; P3345-01.

Figure $7 \quad$ Nothofagidites sp. (fucsa group). Sample 282-13-3, $70 \mathrm{~cm} ; \mathrm{P} 3316-02$.

Figure $8 \quad$ Myrtaceidites parvus Cookson and Pike. Sample 282-12-2, $90 \mathrm{~cm}$; P3312-02.

Figure 9 Proteacidites cf. scaboratus Couper. Sample 28214-3, $70 \mathrm{~cm}$; P3320-01.

Figure $10 \quad$ Proteacidites franktonensis Couper, Sample 2828-3, $70 \mathrm{~cm}$; P3303-01.

Figure 11 Proteacidites clintonensis, Harris. Sample 282-9-1, $115 \mathrm{~cm}$; P3305-01.

Figure 12 Nothofagidites flemingii Couper. Sample 282-13-3, $70 \mathrm{~cm}$; P3316-02.

Figure $13 \quad$ Proteacidites $\mathrm{cf}$. retiformis Couper. Sample 28214-3, $70 \mathrm{~cm}$; P3320-01.

Figure 14 Proteacidites pachypolas Cookson and Pike. Sample 283-9-5, $90 \mathrm{~cm}$; P3347-01.

Figure $15 \quad$ Vitreisporites pallidus (Reissinger). Sample 280A11-3, $69 \mathrm{~cm}$; P3245-01.

Figure 16 Alisporites grandis (Cookson). Sample 280-13-3, $37 \mathrm{~cm}$; P3249-01.

Figures 17, 18 Striatites spp.

17. Sample 282-4-3, $80 \mathrm{~cm}$; P3298-01.

18. Sample 282-8-2, $87 \mathrm{~cm}$; P3302-01.

Figure 19 Zonalapollenites trilobatus Balme. Sample 282-17$1,135 \mathrm{~cm}$; P3311-02.

Figure 20 Densoisporites velatus Weyland and Krieger. Sample 283-9-5, $90 \mathrm{~cm}$; P3347-01.

Figure 21 Coronatispora perforata Dettmann. Sample 282-83, $70 \mathrm{~cm}$; P3303-01.

Figure 22 Lycopodiumsporites austroclavatidites (Cookson). Sample 282-8-2, $87 \mathrm{~cm}$; P3302-01. 
PLATE 4
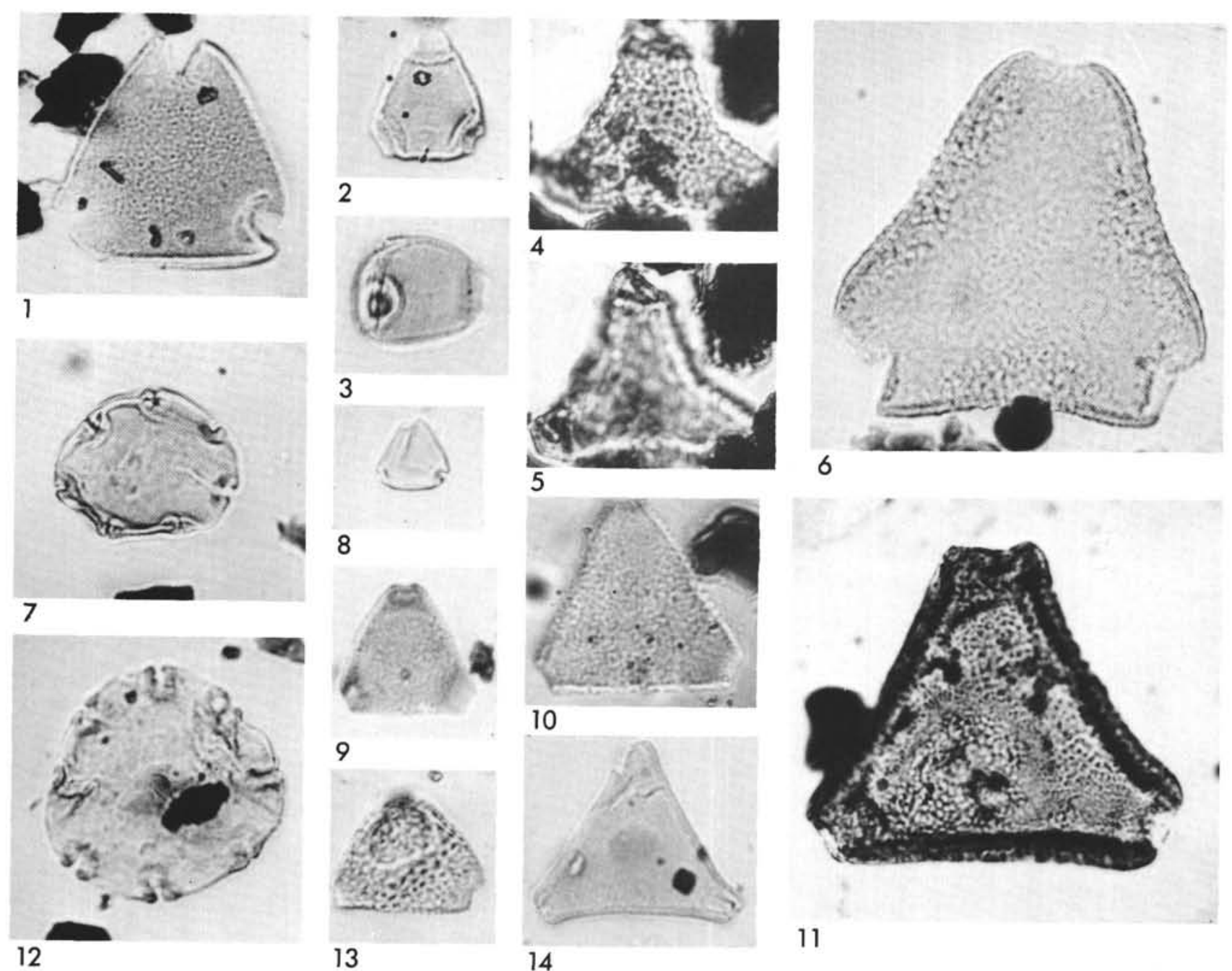

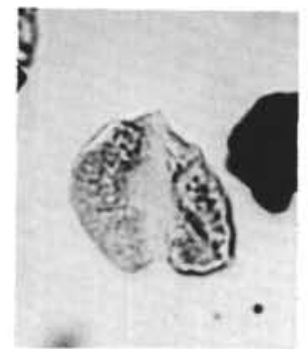

15

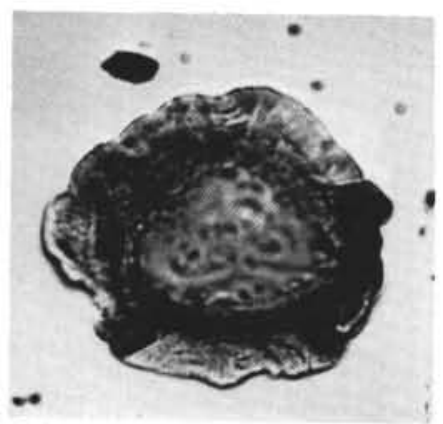

19

16
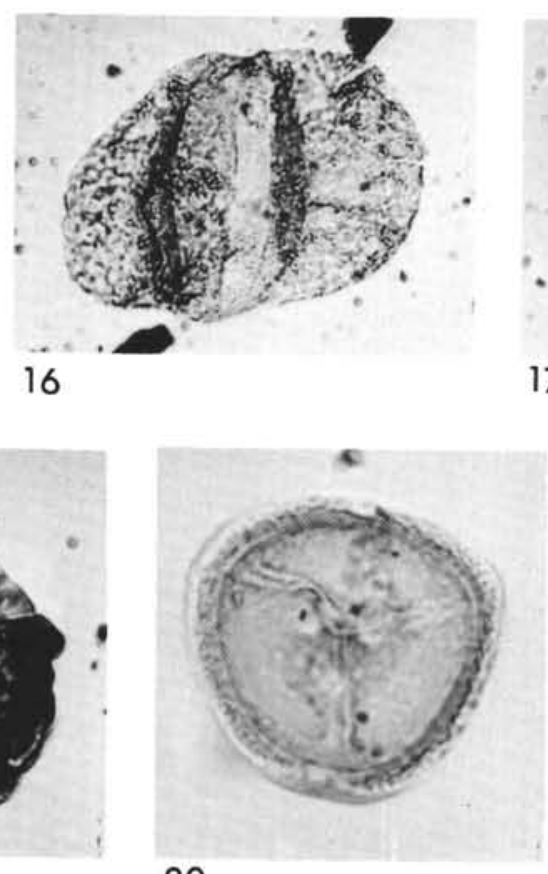

20

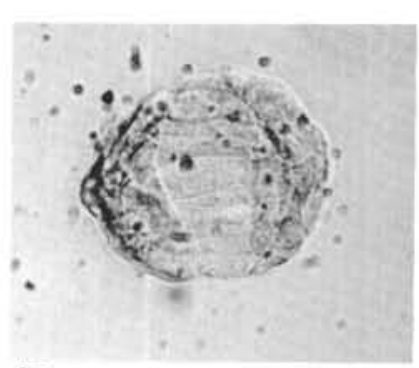

17

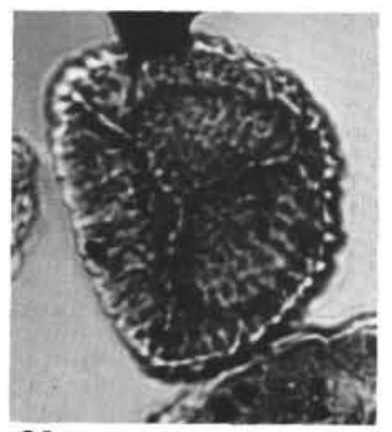

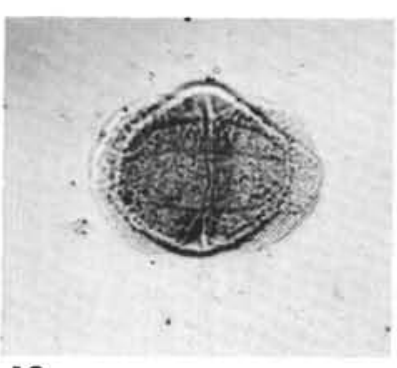

18

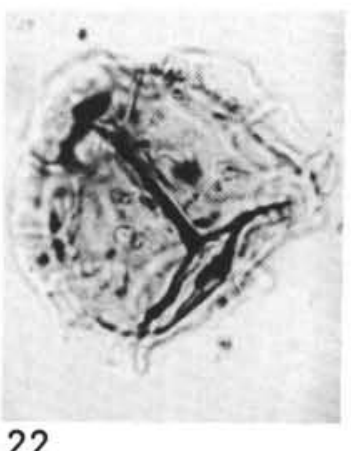

